\title{
Successes rate of endoscopic dacryocystorhinostomy at KMC
}

\author{
Shrestha $\mathrm{S}^{1}$, Kafle PK ${ }^{1}$, Pokhrel $\mathrm{S}^{2}$, Maharjan $\mathbf{M}^{3}$, Toran $\mathrm{KC}^{4}$
}

${ }^{1}$ Assistant Professor, ${ }^{3}$ Lecturer, ${ }^{4}$ Associate Professor, Department of ENT-HNS, ${ }^{2}$ Lecturer, Department of Opthalmology Kathmandu Medical College, Sinamangal, Kathmandu

\begin{abstract}
Background: Nasolacrimal duct obstruction is a common problem which can be corrected by dacryocystorhinostomy (DCR). The gold standard treatment for this is DCR operation through an external approach. Development of endoscopic sinus surgery and endoscopic DCR performed through intranasal route is a major recent development in this field.

Objectives: The aim of this study is to find out the success rate of endoscopic dacryocystorhinostomy without silicon stent intubation within the period of six month following surgery.

Materials and methods: A prospective study was done on 26 patients with obstruction of the nasolacrimal duct referred from eye out-patient department to ENT OPD during one year period from 2008 to 2009. All the cases had undergone endoscopic DCR operation which was regularly followed up for a period of six months. Postoperative patency of ostium was checked by sac syringing and endoscopic visualisation of ostium in the nasal cavity. The success of surgery was categorised as: complete cure, partial cure and no improvement depending upon symptomatic relief and clinical examination such as sac syringing and endoscopic examination following surgery.
\end{abstract}

Result: In six months' follow-up, $22(84.5 \%)$ out of 26 patients had achieved the complete cure and 4 patients (15.5\%) continued to have persistent epiphora.

Conclusion: Endoscopic DCR is a beneficial procedure for nasolacrimal duct obstruction with no external scar on face and less bleeding. The success rate is as good as external DCR.

Key words: Nasolacrimal duct, Epiphora, Rigid nasal endoscope, Endoscopic Dacryocystorhinostomy

$\mathrm{N}$ asolacrimal duct Obstruction is a very common problem and can be corrected by dacryocystorhinostomy through external approach as well as intranasal route with the help of endoscope. The gold standard treatment of the nasolacrimal duct obstruction is DCR operation through an external approach.

Toti in 1904 first performed external DCR for nasolacrimal duct obstruction. This technique has been the gold standard for the treatment of nasolacrimal duct obstruction since then with a success rate of over $90 \%{ }^{1}$. Caldwell, first described the intranasal DCR in $1893^{2}$. It was modified by West and Halle, using microscope for visualizing anatomy of the nose $\mathrm{e}^{3}$. The intranasal DCR was not very popular because of difficulty in visualising the intranasal anatomy.

Development of Endoscopic DCR, performed through an intranasal route, described first in 1989 by MC Donogh $^{3}$, was a major change in this field. Kathmandu Medical College (KMC), ENT department has been performing endoscopic sinus surgery since 2003. However, Endoscopic DCR was performed from 2007 only.
Endoscopic DCR is an effective procedure for treating lacrimal sac and nasolacrimal duct obstruction. This procedure has several advantages over external DCR. It is cosmetically more acceptable because it avoids facial scar and is minimally invasive procedure. It can be done under local anaesthesia. Nasal pathology can be treated simultaneously in the same sitting. It is more physiological because it maintains the lacrimal pump mechanism. In spite of several advantages of Endoscopic DCR, there are higher failure rate due to the obstruction of neo-ostium by granulation and synechia that forms postoperatively ${ }^{4}$. Allen and Berlin reported that one of the reasons for high failure rate of endoscopic DCR operation is due to use of silicon intubation which is responsible for the formation of granulation tissue $e^{5}$ The main aim of this study was to find out the success rate of endoscopic DCR without intubation within the period six months following surgery.

Correspondence

Dr. Sangita Shrestha

Assistant Professor, Department of ENT-HS

Kathmandu Medical College

Sinamangal, Kathmandu

E-mail: sangitadr@yahoo.com 


\section{Materials and methods}

A prospective study was done on 26 patients in the Department of ENT at Kathmandu Medical College, during the period from 2008 to 2009. Initially, all the patients were assessed by ophthalmologist. Patients who had only nasolacrimal duct obstruction were then referred to ENT OPD. The nasolacrimal duct obstruction was confirmed by sac syringing.

All the patients underwent thorough Endoscopic examination of the nasal cavity in ENT OPD. Radiological evaluation such as X-ray PNS and CT scan of nose and paranasal sinus was done to find out the any other nasal pathology. Any predisposing nasal and paranasal conditions were treated at the same sitting at the time of endoscopic DCR. All the patients were operated under general anesthesia (GA).

\section{Surgical procedure}

The nose was prepared and draped using sterile technique. The nasal cavity was packed with ribbon gauze soaked with Xylometazoline $0.1 \%$ or oxymetazoline $0.5 \%$ for 10 minutes. It made shrinkage of nasal mucosa and nasal turbinates so that Endoscope can pass easily in the nasal cavity. The area of lacrimal fossa i.e. the lateral wall of the nose, anterior and superior to the anterior attachment of middle turbinate was infiltrated with 2\% Lignocaine with Adrenaline (1:200,000) with the help of zero degree rigid nasal endoscope $4 \mathrm{~mm}$ in diameter. A U-shaped incision was made in the lateral wall of the nasal cavity anterior and superior to the anterior attachment of middle turbinate with the help of sickle knife. The mucosal flap was elevated with Freer's elevator up to uncinate process to expose the bone overlying the lacrimal sac. The mucosal flap was removed with the help of straight Blakeslay forceps. The exposed bone, overlying the lacrimal sac was gently drilled by cutting burr $(3 \mathrm{~mm})$ until the sac was widely exposed. The bony defect was further widened and smoothened with diamond burr $(3 \mathrm{~mm})$ so that no bony spicules were left to prevent the granulation tissue formation postoperatively. The lower punta was then dilated and a suitable size Bowmam's lacrimal probe was inserted and advanced in the lacrimal sac. It was seen tenting the lacrimal sac which was visualized in the nasal cavity. A vertical incision was made in the medial wall of lacrimal sac and entire medial wall of the sac was removed by upward biting forceps to create a neo- osteum. The patency of ostium was checked by syringing and free flow of irrigating fluid coming out from neo-ostium could be seen by endoscope. A pieces of gelform soaked in steroid eye drop was placed in the bony defect. Light nasal pack was required in cases of concomitant surgery and excessive bleeding.

\section{Postoperative care and follow up}

Patients were put on oral antibiotics, nasal decongestant and steroid eye drop immediately after surgery for a week.

Postoperative follow up was done as follows. The patients were called for follow-up at the interval of 24 hrs, 1 week, 3 week, 6 week, $3^{\text {rd }}$ month and $6^{\text {th }}$ month following surgery. During the follow up both endoscopic examination and syringing of the lacrimal sac were done. Endoscopic visualization of the nasal cavity was done to see the condition of the neo-ostium and the nasal cavity. Syringing of the lacrimal sac was done to observe free flow of irrigated fluid from neoostium.

The success rate of endoscopic DCR was categorized as complete cure, partial cure, no improvement according to degree of symptomatic relief and clinical examination (endoscopic examination and syringing of the sack) following surgery.

\section{Result}

A total of 26 patients, who had obstruction of nasolacrimal duct were referred from ophthalmologist to ENT OPD at KMC, Teaching hospital from 2008 to 2009. These patients were then subjected to endoscopic DCR operation. The patients were followed up routinely at 24 hours, 1 week, 3 week, 6 week, $3^{\text {rd }}$ month and $6^{\text {th }}$ month following surgery. The success of surgery was categorized into complete cure, partial cure and no improvement data analysis was done and following observations were made.

The age of the study group of patients ranged from 17 to 60 years. Of the 26 patients, $15(57.6 \%)$ were female and $11(42.4 \%)$ were male. Out of 26 patients, 3 patients complained of watering of eye with swelling in the medial canthus in the same side. Remaining patients had epiphora alone. There were 16 right sides and 10 left sides (Table 1).

Three patients who had medial canthus swelling had pyocele. One patient having rhinosinusitis with bilateral nasal polyps (Table 1), underwent Functional Endoscopic Sinus Surgery at the same sitting. There was no significant complication during operation. Out of 26 patients 3 patients needed anterior nasal packing which was removed 24 hours following surgery.

Nasal Endoscopic and sac syringing was done during follow up period. Complete cure was achieved in $25(92.3 \%)$ patients at 24 hours following surgery. Subsequent follow up was done on 1 week and 3 week. 
On the 3 week following surgery only 23(88.5\%) patients had complete cure and 2 had partial cure. At $3^{\text {rd }}$ month following surgery $22(84.6 \%)$ patients achieved complete cure and $4(15.3 \%)$ patients had persistent epiphora. The last follow up at $6^{\text {th }}$ month following surgery had shown that same number of patients (as in $3^{\text {rd }}$ month) having achieved complete cure (Table 2).

One patient who had developed nasolacrimal duct block throughout her follow up underwent FESS at same sitting.

Table 1: Site of Eye involvement

\begin{tabular}{|l|c|c|c|c|}
\hline Chief complaints & Rt. Eye & Lt. Eye & Both Eyes & Total \\
\hline Epiphora & 15 & 7 & 0 & 22 \\
\hline Epiphora with swelling in the medial canthus & 1 & 2 & 0 & 3 \\
\hline $\begin{array}{l}\text { Epiphora with bilateral nasal block (nasal } \\
\text { polyps) }\end{array}$ & & 1 & & 1 \\
\hline
\end{tabular}

Table 2: Subsequent follow up

\begin{tabular}{|l|c|c|c|c|c|c|}
\hline $\begin{array}{l}\text { Category } \\
\text { of surgical } \\
\text { success }\end{array}$ & $\begin{array}{c}\mathbf{2 4} \text { hours } \\
\text { following } \\
\text { surgery }\end{array}$ & $\begin{array}{c}\mathbf{1} \text { week } \\
\text { following } \\
\text { surgery }\end{array}$ & $\begin{array}{c}\text { 3 week } \\
\text { following } \\
\text { surgery }\end{array}$ & $\begin{array}{c}\text { 6 week } \\
\text { following } \\
\text { surgery }\end{array}$ & $\begin{array}{c}\mathbf{3}^{\text {rd }} \text { month } \\
\text { following } \\
\text { surgery }\end{array}$ & $\begin{array}{c}\mathbf{6}^{\text {th }} \text { month } \\
\text { following } \\
\text { surgery }\end{array}$ \\
\hline Complete cure & 25 & 25 & 23 & 23 & 22 & 22 \\
\hline Partial cure & 0 & 0 & 2 & 0 & 0 & 0 \\
\hline No cure & 1 & 1 & 1 & 3 & 4 & 4 \\
\hline No. of patients & 26 & 26 & 26 & 26 & 26 & 26 \\
\hline
\end{tabular}

\section{Discussion}

In this study an attempt has been made to find out the success rate of endoscopic DCR operation in our set up within the period of $6^{\text {th }}$ months following surgery. No standard criterion for judging the success rates of lacrimal surgery has been published. Different studies use different criteria of success and varying patient selection. The Royal collage of ophthalmologist published guideline for clinical governance suggests that freedom from epiphora 3 months after surgery is the marker for satisfactory procedure ${ }^{6}$. M W Yung, in 2002 suggests relief of symptoms as the measure of success for surgery with follow up at 6 and 12 months following surgery ${ }^{7}$. Most of the authors has categorized the success rate of Endoscopic DCR into complete cure, partial cure and no improvement depending upon the symptomatic relief and clinical examination such as sac syringing and Endoscopic visualization of neo-ostium. We had also used the above criteria for success rate of surgery in this study. The same criteria were used by Surinder K. Singhall ${ }^{8}$.

Of all the patients with pyocele and those rewuiring anterior nasal packing also had patent ducts later on.

Endoscopic DCR is an alternative to external DCR for management of nasolacrimal duct obstruction. Success rate of external DCR was almost same as endoscopic DCR. The success rate of Endoscopic DCR was $84 \%$ in our study. In reviewing the success rate, the first was Rice who reported on four patients with a $100 \%$ success rate $^{9}$. In 1943, Whittet reported on 40 patients with an $83 \%$ success rate ${ }^{10}$. Weidenbocher from Germany had an $86 \%$ success rate ${ }^{11}$. Camara had reported in his study in 2000 that success rate of Endoscopic DCR ranges from $70 \%$ to $95 \%{ }^{12}$. Sprekelson had reported a large series of patients and had a $96 \%$ success rate ${ }^{13}$. Surinder K, Singhal et.al had reported $89.7 \%$ success rate without intubation $^{8}$. Likewise success rate of endoscopic DCR with intubation was 82 to $95 \%{ }^{13,14,5}$.

Our success rate of endoscopic DCR (84\%) was similar to the rates (81-87\%) reported without intubation ${ }^{16,17,18}$. There were 4 failure cases out of 26 cases operated. Majority of the recurrence occurred within the $6^{\text {th }}$ week following surgery. Two of them had adhesion around the neo- ostium and $3^{\text {rd }}$ case had developed canalicular block during follow up period without definite cause. $4^{\text {th }}$ case that developed nosolacrimal duct obstruction had undergone FESS at same sitting.

\section{Conclusion}

Endoscopic DCR should be considered as a first choice of treatment for nasalacrimal duct obstruction for the following reasons:

- It is simple and minimally invasive procedure.

- No external scar on face and less intra-operative bleeding.

- Nasal and paranasal pathology can be corrected at same sitting. 
- The success rate was $84 \%$ which is as good as external DCR (75to99\%).

- Close follow up immediately after surgery is needed to reduce the failure rate.

- Regular post operative follow up is necessary and any defect like synechia and granulation tissue formation can be released at follow up period thus increasing the success rate.

Endoscopic DCR is a beneficial procedure for nasolacrimal duct obstruction with no external scar on face and less bleeding. The success rate is as good as external DCR.

\section{References}

1. Roper-Hall MJ.Stallard's eye surgery. 7th edition. Oxford: Wright; 1989.

2. Metson R, Noog JJ, Puliafito LA. Endoscopic laser dacryocystorhinostomy. Laryngoscope. 1994;104:269-74.

3. McDonogh M. Meining JH. Endoscopic transnasal dacryocystorhinostomy. J Laryngol Otol. 1989;103:585-7.

4. Hehar SS. Jones NS. Sadiq A,Downes RN. Endoscopic holmium: YAG Laser dacryocystorhinostomy is safe and effective as a day care procedure. J LaryngolOtol. 1997;111:1056-9.

5. Unlu HH, Toprak B, Aslan A, Guler C. Comparision of surgical outcome in primary endoscopic dacryocystorhinostomy without silicon intubation. Ann Otol Rhinol Laryngol. 2002;111:704-9.

6. Royal collage of ophthalmologist. Guideline for clinical governance in ophthalmology. London: RCO; April 1993.

7. MWYung, S Hardman-Lea. Analysis of the result of surgical endoscopic dacryocystorhinostomy: effect of level of obstruction. British jornal ophthalmol. 2002;86:792-4.
8. Surinder K. Singhal, S Bansal, A Dass, S.K. Arya \& N. M. Nagarkar. Endoscopic Dacryocystorhinostomy without stent: Analysis of 37 patients. The internal journal of otolaryngology. 2005;4:1.

9. Rice D. Endoscopic intranasal dacryocystorhinostomy result in four patients. Arch Otolaryngol Head Neck Surg. 1990;116:1061.

10. WhittetHB, Shun-Shin GA, Awdry P.Functional endoscopic transnasal dacryocystorhinostomy. Eye. 1993; 7: 545-9.

11. Weidenbecher M, Hoseman W, Buhr W. Endoscopic endonasal dacryocystorhinostomy. Result in 56 patients. Ann Otol Rhinol Laryngol. 1994;103:363-7.

12. Camara JG, Bengzon AU, Henson RD. The safety and efficacy of mitomycine $\mathrm{C}$ in endonasal endoscopic laser- assited dacryocystorhinostomy. Opthal PLast Reconstr Surg. 2000;16:114-8.

13. Sperkelsen MB, Barberan MT. Endoscopic dacryocystorhinostomy : Surgical technique and result. Laryngoscope. 1996; 106:187-9.

14. Jb Mhapankar, Ra Bradoo, Anagha Joshi, Napur Kapoor, As Ahuja. Endoscopic Dacryocystorhinostomy: An analysis of 16 patients. Bombay Hospital journal. 2002; 44:1.

15. Allen K, Berlin AJ. Dacryocystorhinostomy failure associatd with nasolacrimal silicon intibation. Ophthalmis Surg. 1989;20(7):486509.

16. Mrtimore S, Banhegy GY, Lancaster JL, Karkanevatos A. Endoscopic dacryocystorhinostomy without silicon stenting. JR Coll Surg Edinb. 1999;44:371-3.

17. Lee TS, Kim SW.The effect of placement of bicanalicular silicon tube and silicon stent on granuloma formation in endoscopic intranasal dacryocystorhinostomy. J Korean Ophthalmol Soc. 1999; 40: 16-22. 